\title{
A fogyasztói kutatások története
}

\author{
Kozák Ákos \\ Budapesti Gazdasági Egyetem
}

\begin{abstract}
A TANULMÁNY CÉLJA
A tanulmány célja az, hogy a fogyasztói kutatások hazai és nemzetközi történetének elmúlt 50 évéröl áttekintést nyújtson, annak tematikai és módszertani vonatkozásait figyelembe véve. Miután a fogyasztói kultúra kutatása alapvetően a szociológusok és a kulturális antropológusok terrénuma, az írás elsősorban a fogyasztás elsődleges funkciójával és jelentéstartományával foglalkozik. Ugyanígy nem tér ki az életmód vizsgálatokra és a fogyasztásszociológia modellalkotási gyakorlatára. A tanulmány alapvetően a marketing címszó és diszciplína alatt található toposzokat veszi górcső alá, egyaránt kitérve az akadémiai és az üzleti célú fogyasztói kutatásokra.
\end{abstract}

\begin{abstract}
ALKALMAZOTT MÓDSZEREK
Az alkalmazott módszertant illetően elsődlegesen az irodalmi feldolgozás jöhetett szóba, hiszen primer adatfelvételre értelemszerủen a téma nem ad lehetőséget. Ugyanakkor a szekunder adatforrások feldolgozása során számos olyan anyag került a látókörbe, amelyek akkurátus tartalomelemzési és statisztikai módszert alkalmaztak. A tanulmány mind a nemzetközi, mind a hazai szakirodalmat fel kívánta tárni, de végeredményképpen alapvetően az angolszász gyakorlat bemutatására szorítkozott, abból fakadóan, hogy ezen a nyelven voltak elérhetők releváns adatforrások.
\end{abstract}

\section{LEGFONTOSABB EREDMÉNYEK, ÚJDONSÁGOK}

A fogyasztási kutatásokkal kapcsolatos megállapítások között az egyik leglényegesebb, hogy egyrészt az a fókusztévesztés, amely a társtudományokban, különösképpen a szociológiában tetten érhető az elmúlt évtizedekben, itt kevésbé érvényesül. Másrészt a diszkrepancia az üzleti (vállalati) és akadémia/egyetemi kutatások között általánosnak tekinthető. Továbbá lényeges módszertani dilemma az is, hogy a fogyasztói kutatásnak el kell-e mennie az interdiszciplinaritás irányába, avagy maradjon meg egy, a társtudományok tudásbázisán építkező, multidiszciplináris téma? Egy további fontos megállapítása a szakirodalom feldolgozásának az, hogy a fogyasztói kutatásoknak a vásárlói kutatásra áttevődött hangsúlya egyaránt megragadható a tudományos szakirodalomban és az üzleti gyakorlatban.

\section{GYAKORLATI/GAZDASÁGPOLITIKAI JAVASLATOK}

A fogyasztásszociológia és a fogyasztói kutatások kanonizálása érdekében továbbra is szükség van arra, hogy a fogyasztói kutatásokat a megfelelő helyre lehessen pozícionálni. Az a dilemma, hogy a marketing a közgazdaságtan, esetleg a szociológia és/vagy antropológia tárgykörhöz tartozik-e - azért érdemes tisztázni, mert akkor erőteljesebb fókusz kerül a fogyasztói kutatásokra.

Kulcsszavak: interdiszciplináris, fogyasztói- és vásárlói kutatások, fogyasztásszociológia

DOI: https://doi.org/10.15170/MM.2019.53.02.01 


\section{BEVEZETÉS}

A fogyasztás, mint egyéni aktus, és mint társadalmi aktivitás is érdeklődésre tart számot a közgazdaság- és a társadalomtudomány müvelői számára. Egyrészt lényeges vonatkozásai vannak a makróökonómia terén az intézményes és a háztartási szintű adatok elemzéséböl. A közgazdaság vállalati szintű megközelítése pedig szükségessé teszi a fogyasztók mozgatórugóinak vizsgálatát és az összefüggések folyamatos feltárását. Ebben az értelemben a marketing - és ezen belül a fogyasztói magatartás - ennek a célfüggvénynek egy tagja és egyben a fogyasztással foglalkozó diszciplinák primér tárgya. A humán tudományok sora viszont a fogyasztás egyéb aspektusaira helyezi a hangsúlyt, ahol az egyének a társadalmi pozíciójukat és aspirációjukat demonstrálják. Ez utóbbit én a társadalmi interakciók különböző magyarázó modelljei közé sorolom, és nem tekintem a tudományos megfigyelés közvetlen objektumának.

Miközben a marketing és más üzleti tudományok terén bőséges irodalmi feldolgozás áll rendelkezésre, vannak bizonyos kutatási témák, amelyek eddig nem kerültek a figyelem homlokterébe. A korábbi kutató társadalmon nem lehet számon kérni, hogy miért nem készültek az adott témakört átfogóan tárgyaló tanulmányok. Ugyanakkor egy sokakat érintő és a hazai marketing- és szociológiaoktatástól sem intakt tematika kronológiájának, illetve tartalmi vonatkozásait illető számvetésnek megvan a helye. Ez az írás nem érinti a szociológia terrénumába tartozó életmód-vizsgálatokat és a fogyasztásszociológia sajátos - erősen teoretizáló - modellalkotási gyakorlatát. Ugyanígy nélkülöznünk kell a fogyasztói kultúra társadalmi beágyazottságáról szóló tudományos kutatások bemutatását is, mert az primer értelemben nem tartozik a marketing diszciplínájába, túlnyomó részben a szociológusok és kulturális antropológusok érzik magukénak. Az írás ezért a fogyasztás elsődleges (bizonyos értelemben profán) jelentéstartományában tárgyalja a témát. A tanulmány célja az, hogy áttekintést nyújtson a - gazdaság- és társadalomtörténet modern periódusához köthető fogyasztástól szóló (tudományos) munkásság kanonizációjáról.

A fogyasztói kutatásokkal kapcsolatosan az elmúlt évtizedekben három területen történtek karakterisztikus változások. Egyrészt a vállalati (üzleti) versus egyetemi (akadémiai - és itt most ezt kezeljük egyben) kutatások dichotómiája, másrészt az akadémiai igényü kutatások fókuszkeresése és emellett az üzleti fogyasztói kutatások céljainak diszkrepanciája szembeötlik a témát kutatóknak. Továbbá legalább ennyire lényeges az alkalmazott módszertan, ennek fejlődéstörténete. Amikor hozzáfogtam a nemzetközi szakirodalom feldolgozásához, bíztam benne, hogy angol nyelvủ forrásokon túl találok német nyelvüeket is. Munkám során azonban alapvetően angolszász szerzők munkáját használhattam és sajnos még kedvezötlenebb volt a helyzet a hazai tartalmakkal. Mindez annyit jelent, hogy nem zárhatom ki, miszerint más nyelven íródott a témában összegző írás, de azt gondolom, hogy egy fajsúlyos tanulmány bekerült volna az angol nyelvü szakmai kánonba. Egyetemi kutatói minőségemben csak korlátozott ismeretekhez jutottam, elsősorban az üzleti kutatások terén szerzett tapasztalataimat építettem be az írásba.

A vállalati kutatások értelemszerúen egy adott üzleti probléma feltárására és a lehetséges megoldások keresésére irányulnak. Ahogy erre a későbbiekben kitérek, ez nem azt jelenti, hogy az üzleti szereplők nem vállalhatnak fel ágazati, sőt akár ezen túlnyúló, egy tudományos diszciplínát támogató szakmai témát. De a vállalatoknál a fősodorban mégis olyan kérdések szerepelnek, mint a márkaválasztás, márkahüség, életstílus, a vásárlói út és döntési mechanizmus, vagy a piacbefolyásoló tényezők szerepe és ezek egymásra hatása. Természesen más és más volt a figyelem középpontjában a kilencvenes évek elején és más van a válságot követően. Huszonöt-harminc éve a vállalatok lénygében megismerő-feltáró méréseket végeztettek az akkor még szükebb létszámú piackutató ügynökségekkel. A márka ismerete akkoriban még korlátozó tényező volt, hiszen modern disztribúciós csatornák, és megfelelő kommunikációs eszközök sem voltak (például a kereskedelmi televíziózás is csak 1997-ben kezdődött). Így tehát vizsgálatok sora irányult a piaci bevezethetőség és potenciál feltérképezésére. Ez utóbbit szolgálták az azóta erősen megritkult alapozó (Usage \& Attitude) kutatások. Már ekkor, egészen a kilencvenes évek elején felmerült az igény életstílus eredmények reklám- és médiatervezési alkalmazására. Ennek hátterében a reklámügynökségek álltak és ők írták ki az első tendereket is. Ekkor zajlottak az első müszeres mérések, és ezek az ún. pszichometrikus vizsgálatok tudomásom szerint lényegében hirdetések tesztelésére szolgáltak (leginkább pre-teszt fázisban végeztem magam is galvanométeres és tachisztoszkópos méréseket). 


\section{A HAZAI GYAKORLAT}

A vállalati fogyasztói kutatások történetét a kereskedelem és a tágabban értelmezett fogyasztói társadalom történései írták. Amikor a kiskereskedelmi környezet modernizálódni kezdett, és az első bevásárlóközpontok 1996-ban megnyitottak, a marketingesek figyelme lassan átkerült a vásárlásra és az eladóhelyi viselkedés tanulmányozására. Ez az érdeklődés azóta sem lankad, hiszen a vásárlói döntések jelentős része az üzletben történik. A fogyasztói kutatásoknak ez a módosulása a mérési technológiákat terén is újat hozott és már a kétezres években előkerült a szemkamerás metódus. Bár Király József munkapszichológus már a hatvanas években használt szemkamerát (Király 1964), marketing és így üzleti célból azelött nem alkalmazták. Azóta számos hazai projekt járult hozzá a trade marketingesek munkájának sikeréhez és a hatékony tervezéshez. A kétezres évek bővülö fogyasztási környezete új szokásokkal és termékkoncepciókkal szegélyezte a fogyasztási mintázatokat. Az egészségtudatosság megjelenése és a dinamikusan növekvő fogyasztás vállalatok sorát csábította addig nem ismert jószágok piaci bevezetésére, amit azután a marketingesek kutatási kérdésekké formáltak.

2014-ben az én kezdeményezésemre indult el a hazai társadalom rétegződését feltáró hiánypótló kutatás. Az Akadémia kutatócsoportjával közösen végzett - szokatlanul nagy mintán, tizenöt ezer fö bevonásával zajlott Osztálylétszám vizsgálat (GfK - MTATK, 2014) mind módszertanában, mind az eredmények disszeminációjában szokatlan volt. A kutatás outputjait vállalatok sora ismerte meg, amelynek hátterében nem csupán a tudományos érdeklődés állt, hanem a stratifikációs kérdéskörökön túlmenő média és fogyasztási kérdésblokkok tartalma is számot tartott széleskörü érdeklődésre. Ennek a mérésnek jól megágyazott a 2008-ban szintén saját iniciálásomra létrejött fogyasztás alapú rétegződés vizsgálat (GfK-Tárki 2008). A közel egy évtizede lezajlott kutatás a GfK és a Tárki kooperációjában valósult meg és tartalmi megközelítésében, illetve módszertanában a legigényesebb akadémiai kritériumokat is kielégítette. Az utóbbi kettő kutatási programot vélhetően más tudományos igényü - és valójában alapkutatásnak tekinthető - projektek egészítik ki, ezek azonban nem váltak ismertté a nagyközönség előtt.

$\mathrm{Az}$ üzleti területen dolgozó, professzionális kutatóügynökségek (vagy legalábbis szük csoportjuk) időközönként felvállalnak olyan kutatási témákat, amelyek primer módon az egyetemi vagy akár az akadémiai kutatóintézetek alapfeladata. Természetesen ezt az teszi lehetővé, hogy vannak elkötelezett támogatók a vállalati finanszírozói körből, akik a napi információs igényeken túl is látnak hasznosítható eredményeket ezekből a projektekböl.

$\mathrm{Az}$ egyetemi és akadémiai intézményhálózati fogyasztási kutatásokat ezen a ponton szeretném különválasztani. Tudniillik a Pécsi Tudományegyetem, a Szegedi Tudományegyetem és a Budapesti Corvinus Egyetem tevékenysége ezen a területen kiemelkedő. A Szegedi Tudományegyetem oktatói, Hetesi Erzsébet, Veres Zoltán és Andics Jenő szervezésében - és az OTKA program keretében 2007-2010 között - megvalósult unikális fogyasztásszociológiai vizsgálat nagyban hozzájárult a téma felértékelödéséhez. Ugyanilyen jelentőségủ a Pécsi Tudományegyetemen oktató Törőcsik Máriához köthető életstílus- és trendvizsgálatok sora, amely abban tér el az elözőtől, hogy több évtizedes munkásságot ölel fel a témában. Nem maradhat ki a felsorolásból a Budapesti Corvinus Egyetem oktatógárdája sem, a korábban Molnár Lászlót, Hoffmann Istvánnét soraik között tudó kutatókat később a Hofmeister-Tóth Ágneshez kötődő csapat követte. Ahogy az üzleti szférában, bizonyosan más föiskolai és egyetemi keretben is készültek további vizsgálatok a tárgykörben, de a legjelentősebb és a témát rendszeresen feldolgozó munkásság az előző intézményekhez sorolható.

\section{A FOGYASZTÓKUTATÁS TÖRTÉNETE MADÁRTÁVLATBÓL}

A tanulmánynak nem célja, hogy a fogyasztói társadalom kialakulása körüli polémiák sorát bővítse, és ahogy erre később kitérek, létezik egyfajta megegyezés ebben a kérdésben. Miután a fogyasztói kutatások bizonyosan nem nyúlnak vissza a huszadik századot megelőző korszakokra, érdemes egy ezzel - időben - adekvát modellt alapul venni. Lipovetsky (2005) háromfázisú modellje kézenfekvő számunkra, a szakaszolás igazodik a marketingben ismert nagy korszakokhoz.

1. Az 1880-as évektől az első világháborúig tartó periódus a tömegtermelés és a tömegmarketing kiépülése. Ebben az időszakban alakulnak ki a korszerủ szállítási és kommunikációs infrastruktúrák és a munkaszervezés tudományos formái. A városiasodás és a nők munkába állása és az életszervezés modernizációja életre hívta a csomagolást, a márkázást, majd később az első áruházakat. 
2. A második világháború után, az ötvenes évektől a nyolcvanas évekig tart a bőség és gazdagság periódusa. A hedonizmus, a költési hajlandóság legyőzte a megtakarítási szándékot és az életstílusban pedig elkövetkezett az individualizáció és saját tapasztalás megélése.

3. A nyolcvanas évektől napjainkig tartó időszak, a fogyasztás a társadalmi létegészét áthatja. Ez a kísérletezés és emóciók kiteljesedésének korszaka, ahol nem a másoktól való megkülönböztetés a lényeges, hanem a teljes élvezet megélése. A fogyasztás individualista értelmezést kapott (öncél).

Hozzáteszem, hogy Lipovetsky (2005) utolsó periódusa véleményem szerint inkább a 2008-as válságig volt érvényes és azóta élesebb kontúrt vett fel a moderált, de legalábbis tudatos fogyasztás.

Nemcsak a közgazdaságtanban, hanem a szociológiában is paradigma-váltás történt az elmúlt közel másfél évszázadban. A fogyasztás már nem mellékterméke a társadalmi viszonyokat alakító folyamatoknak, hanem azok központi eleme és teret nyert a fogyasztás társadalmi rétegződésre gyakorolt hatása, differenciátor szerepe. A fogyasztás helyszíne áttevődik az otthonra, a középosztálybeli feleség dolgozik és háztartás-menedzseri szerepet ölt, amelyben a lakásberendezés, fürdőszoba, konyha és adminisztratív teendők egy komplex fogyasztási ökoszisztémát alkotnak. Ugyanakkor ennek a háztartási egységnek a lokalizálhatósága és megszólíthatósága (elérhetősége) a lehetőségek tárházát nyitja ki a marketing iparág számára. A társadalmi mozgatórugók, mint keretrendszer és a bennük zajló folyamatok megértéséhez elég Slater (1997) megközelítését magunkévá tenni. Slater (1997) szerint a fogyasztás a modern társadalmak létrehozója, a modern világban a fogyasztás az, amin keresztül az identitás meghatározódik, a kapcsolatok szerveződnek, a társadalmi aktusok zajlanak.

A fogyasztói társadalom kialakulását és terjedését, továbbá a fogyasztás társadalomszervező erejének demonstrálását övező - különösképpen ennek időbeliségét érintő - viták bár nem kerültek nyugvópontra, de a tudományos konszenzus mégis a második világháborút követő periódust jelöli ki a fogyasztói társadalom hajnalának - lásd Campbell (1996), Corrigan (1997), Hankiss (1990), Lemire (1984), McKendrick et al. (1982), Miller (1995, 2005) vonatkozó tanulmányait. Mégis, ahogy azt Engel et al. (1995) kifejtik, bizonyos értelemben a huszadik század első felében is tetten érhető a fogyasztással kapcsolatos ismeretek vizsgálata.
A korszakra, mint környezeti feltételrendszerre az volt jellemző, hogy a kereslet alapvetően meghaladta a termelési kapacitásokat és ekkor kezdődött a tömegmarketing, föleg a reklámipar kiépülése (valójában mindez akkor leginkább az amerikai piacra érvényes). A kiskereskedelem helyi igényeket szolgált ki és a piacok, továbbá a gazdaság egészében dinamikusan bővültek. Ennek a gazdaságtörténeti korszaknak a fogyasztást illetö fejezeteit - ahogy ez más tudományágakban is megfigyelhető - jellemzően az empíriát nélkülöző elméleti megközelítések írták le. Nagymintás adatfelvételek vagy kvalitatív eljárások egyszerűen még nem voltak a gyakorlatban.

A második világháború utáni évtizedek a gazdaságtörténet legprosperálóbb periódusainak egyike volt. A modern kiskereskedelem kialakulását a bevásárlóközpont koncepció és a diszkont megjelenése jelentette és mindkettő alaposan átformálta a vásárlási és fogyasztási szokásokat. Ehhez járult még a televízió - „the Great Salesperson” - penetrálása a kapitalista piacokon, ami viszont a tömegkommunikáció új fogyasztási mintázatát nyomtatta a társadalom mindennapjainak szövetére. Az első években a kereslet még felülmúlta a gyártási kapacitásokat, de ez az ötvenes évek végére megváltozott. Éppen ez utóbbi mozzanat vezetett el a motivációkutatáshoz és a viselkedéstudományok és a pszichológia amúgy is új és kedvező megvilágításba került. A kommunikációs befolyás, attitüdök és a fogyasztói döntések megismerése a kutatók érdeklődésének homlokterébe került, majd a hatvanas évek legvégétől, hetvenes évektől egy új diszciplína fertőzte meg az érdeklődő közönséget; az életstílus kutatásokra fókuszáló iskolák egymást követő modelljei. Nemcsak a surveyek soft téma-megközelítései illetve a kvalitatív eszközök övezték a módszertani megújulást, hanem ekkor kerültek be a fogyasztói kutatások eszköztárába a pszichometrikus eljárások (szemkamera, tachisztoszkóp stb.) is. A számítógépes technológia és kapacitások rakéta gyorsaságú fejlődése azután a feldolgozás sebességét és többváltozós elemzési technikák kiterjedését hozta magával.

A történelmi-gazdaságtörténeti dichotómia, a kétpólusú világrend megszünése merőben új gazdasági és fogyasztási környezetet eredményezett. A globális termelési ökoszisztémák sokszor a globális fogyasztási mintázatok (kényszerű) terjedésével/terjesztésével jár együtt, amelyet még az Új Média mindent átformáló ereje is keretez. E mellett megmaradnak a gazdasági és fogyasztási potenciálok regionális különbségei, de ezek az idő előre haladtával új földrajzi egységeket foglalnak magukba (harminc éve a kelet-európai piacok 
élvezték a transznacionális tőke figyelmét, úgy egy évtizede inkább az ázsiai térségek érdemelik ki ezt a figyelmet). Ennek az eltolódásnak és globális mozgásnak az egyik kitüntetett terepe a keleti életstílus jegyek és szokások behatolása a nyugati civilizációba. Mindez (a globalizáció) felértékelte a nemzetközi kutatások jelentőségét és egyben markánsan visszavetette a helyi/nemzeti kutatások szerepét. Ehhez járul még az akadémiai kutatások visszaszorulása és az itt elmaradó programoknak - az üzleti-vállalati körben történő - pótlása. Eluralkodnak a technicizált mérések, a gyorsaság és a hatékonyság élvez primátust, átírva a tudományos megközelítést. A legfontosabb két változás véleményem szerint a következő:

1. A fogyasztói magatartás megértésének helyébe lépő vásárlói viselkedés kutatás elötérbe kerülésének hátterében egyrészt az áll, hogy az üzleten belüli döntések sokszor lényegesebbek, mint általában a fogyasztási szokások feltárása. Másrészt a helytől független beszerzési-vásárlási aktusok (e-commerce, m-commerce) olyannyira eröre kaptak, hogy egy-egy jószágcsoportnál gyakran a forgalom felét adják.

2. A fluid fogyasztói-vásárlói magatartás, az életstílusok keveredése és a szituatív döntési helyzetek multiplikálódása sokszor megnehezíti az érvényes kutatási kérdések megfogalmazását és a helyes kutatási módszerek megválasztását.

Módszertanban jelentős különbségek vannak a német és az angolszász iskolák között. Az elöbbi a nagymintás, kvantitatív, kemény megközelítést alkalmazza - ehhez hasonló a hazai gyakorlat is. Az angolszász megoldás teret enged a kvalitatív megközelítéseknek is a konzumerizmus és az életvilág kapcsolatának feltárásában. Az etnográfia, megfigyelés inkább jelen van az angolszász kutatási eszköztárban, mint a német iskola követöinek gyakorlatában.

\section{HOL A FÓKUSZ MOSTANÁBAN?}

Amennyiben eltérünk a bevezetőben említett fókuszálástól és újra beemeljük a szociológiai és kulturális antropológiai vonatkozásokat, akkor egy jelentős problémához juthatunk el. Az érvényes kutatási toposzok kijelölése jelenti ma a társadalomtudományok és ezen belül a szociológia egyik sarkalatos problematikáját. A közgazdaságtudomány és ezen belül az ökonometria figyelemre méltó műveket produkált a fogyasztás tárgykörében. A makroökonóniai megközelítések egyik legjelentősebb képviselője Angus Deaton, aki 2015-ben, a jólétről, szegénységről és fogyasztásról szóló munkássága miatt elnyerte a Nobel díjat. A kulturális antropológusok és történészek (például Valuch Tibor és Gyáni Gábor) jó érzékkel nyúltak a fogyasztás témájához. Vörös Miklós az egyike a kevés kulturális antropológusnak, akinek munkássága kiterjed a fogyasztásra, maga is több kutatási témára tett javaslatot (Vörös 1996). A fogyasztás intézményei és helyszínei; a fogyasztás tárgyainak jelentéstartalma; a szubkultúrák szerepe vagy az identitásképző funkció, illetve a fogyasztási stratégiák egyaránt szerepeltek Vörös menüjében.

A szociológia - és részben az antropológia elvesztette fókuszt, ahogyan erről Szelényi Iván személyes hangvételtől sem mentes kiáltványban ír (Szelényi 2016). „Meg kell vallanom, még a „régi szép időkben”, a hatvanas és a hetvenes évek aranykorában is komoly harcok dúltak a kérdésröl, mely szerzők legyenek kötelezőek a szociológiaelméleti kurzusokon. Mostanra még szükebb körü az egyetértés arról, mi a szociológia. Reménytelennek tünik meghatározni fö elméleti témáit, amit néhány interdiszciplináris program csak tovább bövitett: a women's studies, az afrikai-amerikai tanulmányok, az ázsia-amerikai tanulmányok, a latin-amerikai tanulmányok, a kritikai kultúrakutatás és igy tovább. Az oktatásnak és a tudományos vizsgálódásnak mindegyik legitim terepe, ez nem vitás. Meg is kell, hogy legyen a helyük az egyetemen. De ha valamennyit bevonjuk a szociológiába, azzal szinte teljességgel elhalványítjuk szakmánk határait”.

Fontos figyelmeztetés ez a marketing szakemberek számára is, bár tapasztalatom szerint olyan irányú aránytévesztés, ami például Arnould és Thompson (2005) gyüjtéséből kiolvasható, nem jellemző a fogyasztáskutatóknál és en bloc a marketingeseknél sem (1. táblázat). 


\section{1. táblázat: A fogyasztói kultúrával és szokásokkal foglalkozó kutatási programok önkényesen kiválasztott listája}

\begin{tabular}{|c|c|c|}
\hline Context & Author(s) & $\begin{array}{l}\text { Points of theoretical contri- } \\
\text { bution }\end{array}$ \\
\hline $\begin{array}{l}\text { Working class adoption of } \\
\text { business education }\end{array}$ & Allen 2002 & $\begin{array}{l}\text { A sociological theory of tacit } \\
\text { consumer choice }\end{array}$ \\
\hline White-water river rafting & Arnould and Price 1993 & $\begin{array}{l}\text { Defining extended leisure } \\
\text { service encounters and its } \\
\text { implications for customer } \\
\text { satisfaction }\end{array}$ \\
\hline Gift giving and gift reception & $\begin{array}{l}\text { Belk and Coon 1993; Fischer } \\
\text { and Arnold 1990; Joy 2001; } \\
\text { Otnes, Lowrey and Kim 1993; } \\
\text { Ruth, Otnes and Brunel 1999; } \\
\text { Sherry 1983; Wooten } 2000\end{array}$ & $\begin{array}{l}\text { Formation and structuration } \\
\text { of a moral economy; age and } \\
\text { gender role definition and } \\
\text { enactment in consumer society }\end{array}$ \\
\hline Death rituals in Ghana & Bonsu and Belk 2003 & $\begin{array}{l}\text { Postmortem consumer identity } \\
\text { work }\end{array}$ \\
\hline Sky-diving & Celsi, Rose and Leigh 1993 & $\begin{array}{l}\text { A dynamic model of consumer } \\
\text { motivations and cultural } \\
\text { account of consumer risk } \\
\text { taking behaviours }\end{array}$ \\
\hline $\begin{array}{l}\text { Thanksgiving dinners; } \\
\text { ordinary family dinners }\end{array}$ & $\begin{array}{l}\text { Heisley and Levy 1991; } \\
\text { Wallendorf and Arnould } 1991\end{array}$ & $\begin{array}{l}\text { Cultural rituals; construction, } \\
\text { maintenance and negotia- } \\
\text { tion of family relationships } \\
\text { through consumption }\end{array}$ \\
\hline Homeless women & $\begin{array}{l}\text { Hill 1991; Hill and Stamey } \\
1990\end{array}$ & $\begin{array}{l}\text { Materialism and self-iden- } \\
\text { tity in cases of involuntary } \\
\text { disposition }\end{array}$ \\
\hline Urban gay men & Kates 2002 & $\begin{array}{l}\text { Oppositional consumption } \\
\text { practices and the contesting of } \\
\text { gender distinctions }\end{array}$ \\
\hline $\begin{array}{l}\text { Western stock shows and } \\
\text { rodeos }\end{array}$ & Penaloza 2001 & $\begin{array}{l}\text { Consumers' active process in } \\
\text { the coproduction of market- } \\
\text { place meanings and the role of } \\
\text { commodified cultural myths } \\
\text { in mediating marketplace } \\
\text { relationships }\end{array}$ \\
\hline Harley Davidson riders & $\begin{array}{l}\text { Schouten and McAlexander } \\
1995\end{array}$ & $\begin{array}{l}\text { The structure and dynamics } \\
\text { of consumer subcultures and } \\
\text { reworking of identity }\end{array}$ \\
\hline $\begin{array}{l}\text { Expatriates living in } \\
\text { Singapore }\end{array}$ & Thompson and Tambyah 1999 & $\begin{array}{l}\text { An analysis of cosmopolita- } \\
\text { nism as a consumer ideology } \\
\text { and its role in the shaping of } \\
\text { consumer goals }\end{array}$ \\
\hline
\end{tabular}

Forrás: Arnould és Thompson (2005) alapján 
A szerzők egyébiránt nem kifejezetten a témaválasztás partikularitása okán gyüjtötték össze tíz év - fogyasztói kultúrával foglalkozó - programjait, hanem kritikával illették és így elhatárolódtak a Journal of Consumer Reseach (JCR) üzleti, ,,menedzseriális" megközelítésétől.

Ezt a véleményt tükrözi a Columbia Egyetem kutatójának - az üzletnek a fogyasztói kutatásra gyakorolt kedvezötlen hatását taglaló - cikke is (Holbrook 1985). A vásárlói magatartásnak a primátusa az elmúlt két évtizedben árnyékot vet a jószágok használati és fogyasztási aktusaira, ellenben feleslegesen emeli ki a választás (vásárlás) mozzanatát. Holbrook (1985) azt vallotta, hogy több figyelmet kell szentelni a nem-döntéshozói szituációk megismerésére, mint például az életstílus, a fogyasztási életciklusok vagy akár az elégedettség. Ugyanő világított rá arra is, hogy az üzleti és menedzser(iális) célok között különbség van. A menedzserek eredmény orientáltságú szemlélete adott esetben rövidebb távú vállalati célok megvalósításához járul hozzá és így az ezt kiszolgáló márka-, vagy vásárlói magatartás-kutatások is erre irányulnak és nem feltétlenül a hosszú távú vállalati perspektívákra. Cikkében Holbrook egy az Amerikai Marketing Szövetség konferenciáján ismertetett kutatást hozott fel példának. A napi rutinba tartozó vacsorakészítés vajon inkább egy az otthoni környezetet leíró-megértő vizsgálat tárgya (fogyasztói kutatás) vagy a vásárlói szokásokat feltáró (shopping trip) megközelítés? Vállalati szemszögből ma ez jellemzően a második csoportba esne, a dilemma azonban továbbra is fennáll. Gyakorló szakemberként nagyban egyet tudok érteni a szerző álláspontjával, a lassan harmincöt éve lefektetett gondolatok ma is megállják a helyüket.

A fenti táblázat a kilencvenes évekröl szólt, de tanulságos megismernünk a kétezres évek gyakorlatát is (Peighambari et al. 2016). A szerzők felhívják a figyelmet egy az 1950-1981 közötti szakirodalmi feldolgozásra (Helgeson et al. 1984), ök maguk azonban az 1998 és 2009 közötti periódust elemezték öt jegyzett periodika és megközelítöleg 1000 tanulmány alapján. Elöször 2915 cikket vettek be az elemzésbe, majd tartalomelemzéssel 37 témacsoportba rendezték ezeket. Tartalmi szempontból négy klaszter adódott; a pszichológiai faktorokat tárgyaló internális, a vásárlási proceszszust leíró, a környezeti körülményeket körbejáró és a máshová be nem sorolható egyéb kérdéskörök. Az eljárás egy következő szakaszában, követve Helgesonék módszerét, négy módszertani téma köré rendezték a tanulmányokat: surveyek, kísérleti eljárások, diszkussziók és egyebek. A vizsgált tizenkét évben a vásárlói környezettel foglalkozó cikkek száma csökkent, a belső, a vásárló lélektanát feltáró tanulmányok sora azonban gyarapodott. Ugyanígy bővült a vásárlás folyamatát bemutató elemzések számossága, ami a már korábban említett hangsúlyeltolódást jelzi a fogyasztói fókuszról a vásárlóira (1. ábra).

\section{1. ábra: A fogyasztói kutatások négy nagy témakörének fókusza 1998 és 2009 között}

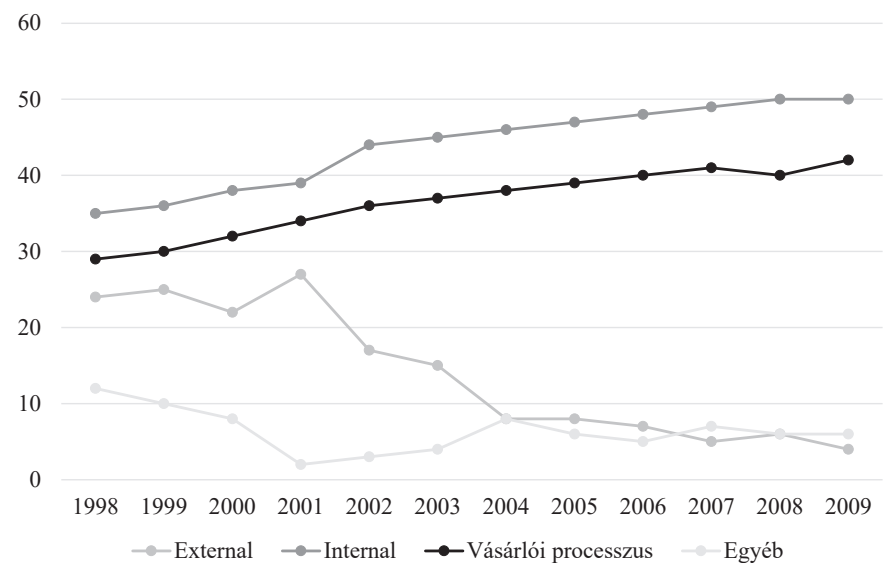

Forrás: Peighambari et al. 2016 
A kritika elér a piackutatás gyakorlatához is (Greig 2003). A Lancaster Egyetem korábbi marketing tanszékvezetője szerint a fogyasztói kutatások és a marketing céljainak közös metszete igen kis területet fed le. A corporate (vállalati) marketinggyakorlat hatékonysági elvárásait a kutatási programok nem teljesítik és diszkrepancia van az elmélet és az üzleti célirányultság között. Véleményem szerint nem kell átfedésben lenniük, de trendjeiben hasonló utat kell követniük. Azt is figyelembe kell venni, hogy mára a vállalati piackutatási profil (még ha consumer insightnak is hívják) még a legnagyobb vállalatokban is gyakran egy közvetítő szerepre szükült. A piackutató lényegében véve a belső megrendelő szervezeti egység (értékesítés, termelés, marketing) információs igényeit, üzleti problémáját tolmácsolja a kiszervezett ügynökségi szakembernek, önálló, különösen modellalkotási tevékenységre nem kerül sor. A helyzet azonban a külső, ügynökségi munkatársak terén sem ígéretesebb. Tapasztalom alapján korlátozott affinitása van a napi rutinba temetkező szakembereknek akár szakmai cikkeket, nemhogy tudományos elemzéseket írni. Greig tovább tetézi kritikáját, amikor azt állítja, hogy az innovációra való általánosan alacsony hajlam nem segíti elö az újszerü kutatási ötletek terjedését. A sor folytatódik azzal, hogy a vezető kutatási eljárások validitása (szerinte) valójában a márkával kapcsolatos marketing aktivitás során derül ki. Egy a modern piackutatással szemben megfogalmazott elvárásra világít rá a szerző, amikor pedig a kutatási design akadémikus (én inkább a didaktikus jelzőt használnám) oktatása felett tör pálcát. Ennek eredménye szerinte, hogy a szakmával foglalkozó könyvek nagy része adatgyűjtéssel, elemzéssel foglalkozik és alig található bennük ötletgenerálás vagy további elméletalkotási javaslatok.

\section{HIERARCHIA A TUDOMÁNY- ÁGAK KÖZÖTT, AVAGY MI JELÖLI KI A FOGYASZTÁS- KUTATÁS POZÍCIÓJÁT?}

A társtudományok képviselői az évtizedek alatt folyamatosan ostorozták a fogyasztáskutatókat. A már felvázolt problémákon túlmenően tetten érhető az inter- vagy multidiszciplinaritást érintő polemizálás is. Az az érzésem, hogy ezek a gyakran erős kritikai éllel született cikkek azt a régóta hangoztatott álláspontot igyekszenek alátámasztani, ami szerint a fogyasztókutatások nem érnek fel a szociológia vagy a pszichológia akadémiai kánonba tartozó tudományágai közé. Ezt a problémát magam is tárgyaltam az életstílus-megközelítésekkel kapcsolatosan (Kozák 2011). Magát a problémafelvetést Journal of Consumer Research exponálta (Ferber 1977). Illeszkedve a folyóirat szellemiségéhez, a szerző a fogyasztói kutatások multidiszciplináris jellege felől az interdiszciplináris megközelítés felé tágította volna a horizontot. Az elsőben egy adott tudományterület képviselöi cserélnek eszmét, a másodikban különböző diszciplinák szereplöi állítanak fókuszba egy toposzt. Az interdiszciplinaritás azért is kívánatos, mert az üzlet és a kormányzati aktorok is bekapcsolódhatnak a kooperációba - vélte Ferber négy évtizede.

Valamivel több, mint három évtizeddel később született egy másik írás, amely ezzel merőben ellentétes oldalon áll (Macinnis \& Folkes 2010). Nem csak Journal of Consumer Research magát interdiszciplinárisnak aposztrofáló beállítottsága ellen emeltek kifogást, hanem végeredményképpen visszatolták a fogyasztói kutatásokat a multidiszciplináris pólusba. Sőt, érvelnek a szerzők, a fogyasztói magatartás a marketing része és sohasem volt különálló tudományág. Az Amerikai Fogyasztáskutató Társaság (AMA) 1969-es alapítása valójában a marketingről való leszakadás jegyében történt és a fogyasztáskutatásnak tudományos jelleget igyekezett kölcsönözni. Ahogy a szociológia eltávolodott a nagy társadalmi toposzoktól, úgy a fogyasztáskutatás a hatvanas évektől Amerikában is rész-problémákat kezdett felölelni, mint például a fogyasztóvédelem vagy a jólét. Macinnis és Folkes (2010) etimológiai magyarázattal is szolgált arra vonatkozóan, hogy egy diszciplína csak akkor állja meg a helyét, ha alá tartozó intézményesített csatornái vannak (tanszékek, egyetemi kutatócsoportok). Továbbá az adott tárgykör szerepel a kognitív szótárban, azaz benne van az akadémiai, egyetemi kánonban. Megvan a saját intellektuális tere, akadémiai legitimációja. Ebben az értelemben a szerzőknek igaza volt és ma is ez a helyzet. Önálló fogyasztáskutatási profillal nem rendelkeznek az egyetemi helyek, sőt, a Szociológiai Társaság vagy a közgazdászok sem emelték be maguk közé. Úgy vélem, hogy önmagában nincs probléma azzal, ha a marketinghez, mint alkalmazott tudományághoz csatoljuk be a fogyasztáskutatást (ahogy ezt a szerzőpáros is javasolta). De ebben az esetben a marketingnek kell ellátnia az integráló szerepet és saját terrénumán belül kell törekednie interdiszciplinaritásra (2. ábra). 


\section{mint a marketing multidiszciplináris komponensének modellje}

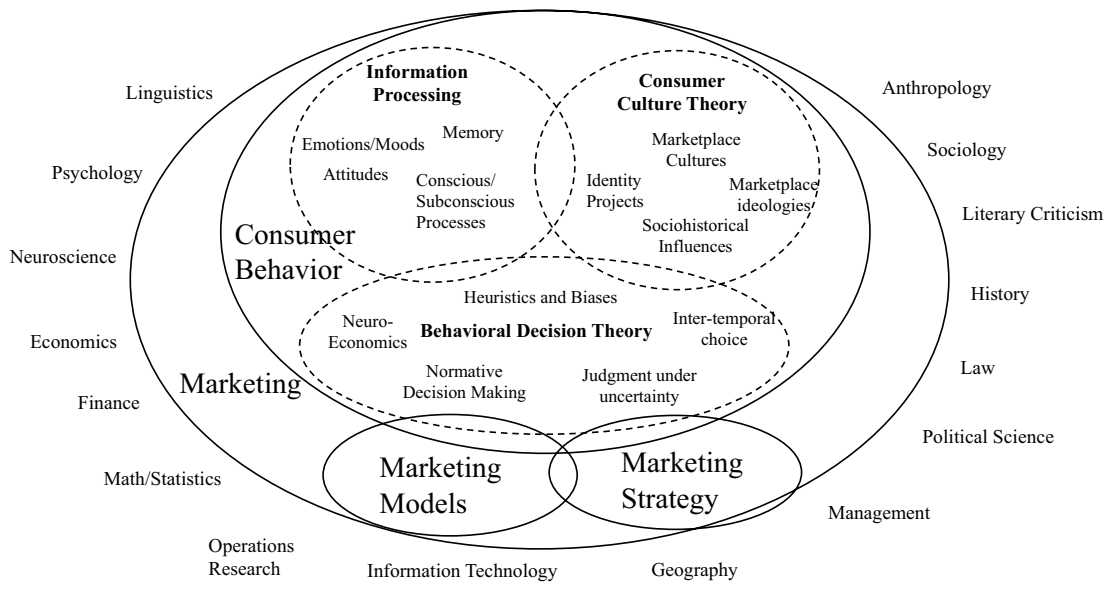

Forrás: MacInnis és Folkes (2009)

A Pécsi Tudományegyetem harmadik éve futó fogyasztáskutatási szimpózium sorozata úttörő és egyben tudományszervezői - szerepet tölt be A közgazdaságtan, antropológia, pszichológia, szociológia, marketing és filozófia képviselőinek évi találkozója az interdiszciplináris megközelítés felé mutat, de a jövőben ki kell választani néhány tematikus csomópontot, amelyen a kutatóknak közösen kell áthaladniuk.

\section{MERRE MENJÜNK TOVÁBB?}

Mielőtt a lehetséges kutatási irányokat tekintenénk át, foglalkoznunk kell néhány jelenlegi dilemmával. Vannak, akik a kutatások átfogó jellegét már a korábbi évtizedekben hiányolták és magam mára vonatkoztatva is osztom nézeteiket (Kollat et al. 1970). Természetes, hogy egy magatartással, viselkedéssel foglalkozó szakmacsoport szétágazó érdeklódési területeket vesz górcső alá. Ha fogyasztókról van szó, körül kell járni társadalmi státuszukat, kognitív képességeiket, beállítódásukat, aspirációjukat, azaz a magatartásukra ható belső és külső tényezőcsoportokat. Ugyanakkor felmerül a kérdés, hogy mennyire lehet priorizálni ezeket annak érdekében, hogy a szakemberek egyegy témacsokorra összpontosítsanak. Ez persze együtt jár módszertani és elemzési harmonizációval is. Már öt évtizede felvetették a szerzők az alkalmazott ismérvek, változók és eljárások sztenderdizálásának igényét és ismerve a mai kutatási spektrum diverzifikációját, erre ma is szükség van. Ugyanennyire lényegbevágó lenne a már 1970-ben felvetett replikációs gyakorlat. Más tudományágakban bevett gyakorlat, sőt kötelező eljárásrendi elem a kutatások megismétlése időközönként. Erre sajnos nem sok példa akad a fogyasztáskutatás nemzetközi és hazai vizein.

A jövő bizonyosan a fogyasztáskutatás széles tárházát kínálja. Új és izgalmas témakörök kerülnek szemünk elé, eddig nem ismert struktúrák és formák tűnnek elö. A közösségi fogyasztás vagy a fogyasztásnak a fenntarthatóság ökoszisztémájában játszott szerepéről való gondolkodás olyan új kutatási kérdések, amelyeket nem kell átengednünk a neobehaviorista közgazdasági, illetve a környezetvédelmi szakembereknek. Már a legújabbkori szociológia is vizsgálatának tárgyává teszi a non-reflexív, azaz a rutinszerü, mindennapi fogyasztást és az ehhez kötődő habitus- és szokásvilágot. De górcső alá kerül az IT-technológia és a digitália diszruptív elterjedése, ezzel összefüggésben a fogyasztás tér- és időbeliségének változása. Továbbá elkezdtek foglalkozni szociológusok és antropológusok a jószágok cirkulációjával, előtérbe került a hulladék növekvő jelentőségű kérdése.

A hangsúlyokat illetően érdemes Miller (2005) felfogásához nyúlnunk (lásd a 2. táblázatot). 
2. táblázat: Az új fogyasztói magatartás kutatása

\begin{tabular}{|ll|}
\hline Régi perspektíva & Új perspektíva \\
\hline Pozitivista & Nem-pozitivista \\
Kvantitatív & Kvalitatív \\
A priori elméletek & Fejlődő elméletek \\
Közgazdasági/Pszichológiai & Szociológiai/Antropológiai \\
Mikroszintű & Makroszintü - kulturális \\
Fókusz a vásárláson & Fókusz a fogyasztáson \\
Kognitív hangsúly & Emocionális hangsúly \\
Amerikai (angolszász) & Multikulturális \\
\hline
\end{tabular}

Forrás: Miller (2005)

Néhány vonatkozást már én is kiemeltem korábban, mint például a kvalitatív eljárások alkalmazása. Érdekes, hogy Miller (2005) (is) visszahelyezné a fókuszt a fogyasztásra a vásárlásról. Itt jegyzem meg, hogy a vállalati (menedzseriális) szempontú és gyakran a vásárlásra vagy annak körülményeire összpontosító mérési praxis megváltoztatásában az elméleti szakembereknek véleményem szerint lassan termőre forduló, lényeges szerepük lesz. A kutatási témák makroszintű kezelése pedig a holisztikus látásmódot fogja eredményezni, különösen akkor, ha a makro jelentéstartalmát nem csak a nemzeti vagy nemzetközi kiterjesztésben értelmezzük, hanem más környezeti alrendszerekkel összefüggésben is. Ha pedig módszertani kontextusban gondolkodunk a tágabb (makro) perspektíván, akkor nyitottak kell lennünk a szociológia, demográfia, történetkutatás és a kulturális antropológia iránt (Solomon 2005). A kutatásoknak a jövőben nem általános, időtől független megállapításokat kell tenniük, hanem egy adott probléma konkrét idősíkjában tett és kontextus-függő eredményt kell nyújtania. Az objektivitásra való törekvés csak korlátozott lehet. Egyrészt az események bekövetkezésének sebessége, másrészt az információs zaj is korlátot szabnak az igazság megismerésének. Fontosabb lehet a társadalmilag konstruált és a dolgokat komplexitásában kezelő szemléletmód, mint egy probléma egyediségének megragadása. Az előrejelzés bár továbbra is lényeges kritérium, de a megértés legalább ennyire fontos. Solomon (2005) jó érzékkel tapint rá arra, hogy a jövő fogyasztói kutatásai a pozitivista irányból el kell, hogy mozduljanak az interpretáló szerepkörbe.

Sheth, mint lehetséges jövőbeni vizsgálódási témákat sorolja fel a következőket (Sheth 2017):
- Fogyasztóiélmény-kutatás vásárlói helyett. Felértékelődik a használat módja és a post-purchase (vásárlás utáni) magatartás.

- Közösségi média elköteleződés/részvétel. Mennyiben, hogyan befolyásolja a vásárlást, ennek útjait?

- Tudatos, odafigyelő (mindful) fogyasztás. A fenntarthatóság és fogyasztás összefüggései (USA: a szénlábnyom hetven százaléka az otthonokban és nem az üzemekben képződik)

- Fogyasztás a tömeg vonzásában (Crowd Consumption). Milyen hatással bír egy fesztivál, egy utcai esemény, egy tömegrendezvény a fogyasztási mintázatra (beleértve a virtuális térben zajló eseményeket is)?

- Multikulturális tényezők. Kisebbségből mintává válni.

- $\quad$ Alacsony jövedelmüek fogyasztásai. Base of Pyramid (BOP), akik napi kettő dollárnál kevesebbet keresnek, de mégis ötezer milliárdos (USD) piacot jelentenek.

Ezek a témakörök bizonyosan nálunk is relevánsak vagy azokká válnak a jövőben. Részemtől mindenképpen javasolom beemelni a kutatási programokba a nemzeti identitásképzés továbbá a geokulturális mintázatoknak a fogyasztásra gyakorolt hatását. A kutatásoknak ki kell terjednie a tágabb környezetre, földrajzi és diszciplináris értelemben is.

A marketing-szakembereknek a jövöben gondosan kell eljárniuk kutatási témaválasztásuk során. Érzékenyen kell reagálniuk a környezeti tényezők változásaira, de szem elött kell tartaniuk a fősodor által irányított szakmai érdeklődést és az adott toposz jövőre mutató relevanciáját. 


\section{HIVATKOZÁSOK}

Arnould, E. J., Thompson, C. J., (2005), "Consumer Culture Theory (CCT): Twenty Years of Research", Journal of Consumer Research, 31 4, 868-82 DOI: https://doi.org/10.1086/426626

Campbell, C. (1996), „A modern fogyasztói étosz rejtélye", Replika, 21-22, 117-37

Corrigan, P. (1997), The Sociology of Consumption: An Introduction, Sage Publications, DOI: http:// dx.doi.org/10.4135/9781446216903

Engel, J. F., Blackwell, R. D. and Miniard, P. W. (1995), Consumer behaviour, Dryden Press Series in Marketing, South-Western; 8th Revised edition edition

Ferber, R. (1977), "Can Consumer Research be Interdisciplinary?" Journal of Consumer Research, 4 3, 189-92 DOI: https://doi. org/10.1086/208699

GfK (2014), Osztálylétszám kutatás, együttmüködésben a Magyar Tudományos Akadémia Társadalomtudományi Központ munkatársaival

GfK-Tárki (2008), Fogyasztói szegmentáció

Greig, I. A. (2003), "Towards a typology of consumer survey research", European Journal of Marketing, 37 10, 1314-31 DOI: https://doi. org/10.1108/03090560310487121

Hankiss E. (1999), A proletár reneszánsz, Helikon kiadó, Budapest

Helgeson, J. G., Kluge, E. A., Mager, J., and Taylor, C. (1984), "Trends in consumer behavior literature: A content analysis", Journal of Consumer Research, 10 4, 449-54 DOI: https://doi. org/10.1086/208985

Hetesi E. - Andics J. - Veres Z. (2007), „Az életstílus-kutatási eredmények fogyasztásszociológiai interpretációs dilemmái”, Szociológiai Szemle, 3-4 115-34

Holbrook, B. M. (1985), "Why Business Is Bad For Consumer Research: The Three Bears Revisited", Advances in Consumer Research, 12 14556

Király J. (1964), Kísérletezö pszichológusok, Gondolat Kiadó, Budapest

Kollat, D. T., Engel, J. F. and Blackwell, R. D. (1970), "Current Problems in Consumer Behavior Research", Journal of Marketing Research, 7 3, 327-32 DOI: https://doi.org/10.2307/3150290

Kozák Á. (2011), A fogyasztói életstílus leirására szolgáló kutatási megközelitések kritikai elemzése, doktori értekezés, Pécsi Tudományegyetem, Regionális Politika és Gazdaságtan Doktori Iskola
Lemire, B. (1984), ’Developing Consumerism and the Ready-Made Clothing Trade in Britain, 1750-1800", Textile History, 15 1, 21-44 DOI: https://doi.org/10.1179/004049684793690443

Lipovetsky, G. (2005), Hypermodern Times, Malden: Polity Press

MacInnis, D. J. and Folkes, V. S. (2010), "The Disciplinary Status of Consumer Behavior: A Sociology of Science Perspective on Key Controversies", Journal of Consumer Research, 36 6, 899-914 DOI: https://doi.org/10.1086/644610

McKendrick, N., Brewer, J. and Plumb, J. H. (1982), The Birth of a Consumer Society: The Commercialization of Eighteenth-Century England, Indiana University Press

Miller, D. (1995), Acknowledging Consumption, Routledge, New York

Miller, D. (2005), „A fogyasztás mítoszai”, Replika, 51-52, 239-56

Peighambari, K., Sattari, S., Kordestani, A. and Oghazi, P. (2016), Consumer Behavior Research, A Synthesis of the Recent Literature, First Published April 26, 2016

Sheth, J. (2017), 'The Future History of Consumer Research: Will the Discipline Rise to the Opportunity?" Advances in Consumer Research, 45 17-20

Slater, D. (1997), Consumer Culture and Modernity, Cambridge: Polity.

Solomon, M. R., Zaichkowsky, J. L. and Polegato, R. (2005), Consumer behaviour: buying, having, and being (3/e.), Toronto: Pearson Prentice Hall

Szelényi I. (2016), A szociológia hármas válsága, Socio.hu (Éber Márk Áron fordításában)

Vörös M. (1996), „Fogyasztás és kultúra”, Replika, 21-22, 77-79 
Kozák Ákos PhD, föiskolai docens

kozak.akos@uni-bge.hu

Budapesti Gazdasági Egyetem

\section{The History of Consumer Research}

\section{THE AIMS OF THE PAPER}

The objective of the study is to offer an overview of the last fifty years of the history of Hungarian and international consumer research taking the thematic and methodological aspects into consideration. Since consumer culture is basically the territory of sociologists and cultural anthropologists, the study mostly concerns the primary function and semantic field of consumption. Similarly, it does not discuss lifestyle research and the models of the sociology of consumption. The study essentially assesses the topics under the headings marketing and discipline, discussing both academic and business related consumer researches.

\section{METHODOLOGY}

As regards the methodology applied, it was mostly the research of the existing special literature that could come into question since the topic certainly does not lend itself to primary field work. At the same time, in the course of the study of the secondary data sources, several subjects using accurate content analysis and statistical methods emerged. The study intended to explore both international and Hungarian special literature, but in effect was limited to presenting the Anglo-Saxon practice due to the fact that relevant data sources were available in the English language.

\section{MOST IMORTANT RESULTS}

One of the most significant findings related to consumption research is that the loss of focus experienced in related social sciences, especially in sociology, is seen here to a lesser extent. On the other hand, the discrepancies between the business (corporate) and academic/university researches can be considered general. A further methodological dilemma of significance is whether consumer research should move towards interdisciplinarity, or should is remain a multidisciplinary topic build on the knowledge base of related social sciences? A further important finding arising from the study of the special literature is that the shift of emphasis towards buyer research in consumer research can be captured in both scientific special literature and business practice.

\section{PROPOSALS CONCERNING PRACTICE/ECONOMIC POLICY}

In order to canonize the sociology of consumption, it is necessary that consumer research be positioned in its 3 proper place. The dilemma whether it belongs in economy, sociology and/or anthropology is worth clarifying because then the focus becomes stronger and clearer on consumer research.

Keywords: interdisciplinary, consumer and buyer research, sociology of consumption 